\title{
The effect of spray drying on the difference in flavor and functional properties of liquid and dried whey proteins, milk proteins, and micellar casein concentrates
}

\author{
Brandon Carter, ${ }^{*}$ Hasmukh Patel, ${ }^{*}$ David M. Barbano, $†$ and MaryAnne Drake ${ }^{* 1}$ \\ *Department of Food, Bioprocessing and Nutrition Sciences, Southeast Dairy Foods Research Center, North Carolina State University, \\ Raleigh 27695 \\ †Department of Food Science, Northeast Dairy Foods Research Center, Cornell University, Ithaca, NY 14853
}

\begin{abstract}
Traditionally most protein ingredients are sold as a powder due to transport ease and longer shelf life. Many high-protein powder ingredients such as milk protein concentrate with $85 \%$ protein and micellar casein concentrate have poor rehydration properties (e.g., solubility) after storage, which might limit their use. An alternative to the production of dried protein ingredients is the option to use liquid protein ingredients, which saves the cost of spray drying, but may also improve flavor and offer different functional properties. The objective of this study was to determine the effect of spray drying on the flavor and functionality of high-protein ingredients. Liquid and dried protein ingredients (whey protein concentrate with $80 \%$ protein, whey protein isolate, milk protein concentrate with $85 \%$ protein, and micellar casein concentrate) were manufactured from the same lot of milk at the North Carolina State University pilot plant. Functional differences were evaluated by measurement of foam stability and heat stability. Heat stability was evaluated by heating at $90^{\circ} \mathrm{C}$ for $0,10,20$, and $30 \mathrm{~min}$ followed by micro-bicinchoninic acid and turbidity loss measurements. Sensory properties were evaluated by descriptive analysis, and volatile compounds were evaluated by gas chromatography-mass spectrometry. No differences were detected in protein heat stability between liquids and powders when spray dried under these conditions. Whey protein concentrate with $80 \%$ protein (liquid or spray dried) did not produce a foam. All powders had higher aroma intensity and cooked flavors compared with liquids. Powder proteins also had low but distinct cardboard flavor concurrent with higher relative abundance of volatile aldehydes compared with liquids. An understanding of how spray drying affects both flavor
\end{abstract}

Received September 2, 2017.

Accepted November 16, 2017.

${ }^{1}$ Corresponding author: maryanne_drake@ncsu.edu and functionality may help food processors better use the ingredients they have available to them.

Key words: dairy protein, spray drying, flavor, functionality

\section{INTRODUCTION}

High-protein ingredients have increased in popularity over the past decade because of the added nutritional, and health benefits (Tunick, 2008). The most popular forms of protein come from milk in the form of milk protein concentrates (MPC) and isolates (MPI), which are made up of casein and whey proteins in the normal ratio found in milk, and whey protein products, which are isolated from cheese whey (Agarwal et al., 2015). The main 2 protein products from the fluid whey stream are whey protein concentrate (WPC), 34 to $89 \%$ protein, and whey protein isolate (WPI), $>90 \%$ protein (US Dairy Export Council, 2004). Micellar casein concentrate (MCC) is made by membrane fractionation of milk where milk serum proteins permeate through the membranes and are separated from caseins. The typical serum protein removal percentage in MCC lies in the range of 60 to $95 \%$, which can create a range of MCC products (Beckman et al., 2010).

Protein has become more popular and profitable as a value-added nutrition ingredient (Tunick, 2008). Protein ingredients also have many useful functional properties, which include thermal stability, gelation, foam formation, and emulsification (de Wit, 1998). Protein is typically sold as a powder because it has a longer shelf life as well as reduced transportation costs. However, for a company that produces both ingredients and finished products, or a company that standardizes protein or milk solids with powder, it might be more advantageous to use liquid protein concentrates in consumer products as opposed to drying the protein first, then incorporating it into the final product.

Spray drying involves the atomization of a liquid into hot air chamber to remove water (Henning et al., 2006) 
and often includes preliminary heat-driven evaporator concentration under vacuum before spray drying. Spray drying is an expensive high-heat process and is the most common form of drying protein in the dairy industry in the United States. Higher heat processes have been associated with undesirable flavors caused by lipid oxidation, Maillard reaction products, and other volatile flavor formation (Smith et al., 2016a). Spray drying also reduces protein yield through mechanisms such as wall deposition, which can lead to reduced protein recovery and potential profit (Ozmen and Langrish, 2003). Several studies have evaluated or reviewed the literature as it pertains to the effect of spray drying parameters on particle size, particle morphology, surface free fat, and protein denaturation of milk powder, milk protein concentrates, and whey proteins (Gaiani et al., 2010; Fang et al., 2012; Schuck et al., 2013; Park et al., 2014b; Nikolova et al., 2015; Uluko et al., 2016). The process of spray drying causes some unavoidable losses in protein functionality due to difficulties with reconstitution as well as the dehydration process that occurs during spray drying can cause aggregation and denaturation (Augustin and Udabage, 2007). Using the liquid retentate, as opposed to spray drying, may then potentially increase protein yield as well as improve flavor, but have different functionality than a dried product. Previous studies have not, to our knowledge, compared the liquid concentrated protein retentate to the spray dried powder, and none to our knowledge, have considered the effect on flavor.

Flavors present in protein ingredients affect flavor of formulated foods (Morr and Ha, 1991; Lee and Morr, 1994; Drake, 2006; Childs et al., 2007). Protein ingredients are typically not included in ingredient applications for their flavor; therefore, the goal in ingredient processing is to produce a bland and clean flavored ingredient (Drake et al., 2009). Many processing operations, however, have an effect on the flavor of protein ingredients and can encourage off flavor development. Storage of whey or fluid milk at any step of the filtration process or evaporation can increase off-flavors (Whitson et al., 2010; Campbell et al., 2011; Park and Drake, 2016; Park et al., 2016a). Park et al. (2014b, 2016b) demonstrated that changing the feeds solids concentration and inlet temperature of the spray dryer affected off-flavor development in dried whey protein powder, skim milk powder, and MPC 70 (throughout, numbers indicate the percentage of protein). Even finished powder unit operations such as steam agglomeration and instantizing can increase off-flavor intensities (Wright et al., 2009; White et al., 2013). The flavor intensities of dried protein ingredients are low, but these low intensities are detected by consumers in ingredient applications and negatively affect acceptability (Caudle et al., 2005; Wright et al., 2009; Evans et al., 2010; Childs and Drake, 2010). Therefore, it is important to consider how each unit operation affects the flavor of the dried ingredient and how that will affect the final product application. The objective of this study was to determine the effect of spray drying on the flavor and functionality of WPC 80, WPI, MPC 85, and MCC.

\section{MATERIALS AND METHODS}

\section{Protein Manufacture}

All proteins were manufactured at the North Carolina State University Dairy Research Pilot Plant (Raleigh). Each protein was produced in triplicate.

\section{WPC 80 Production}

Raw whole milk, $380 \mathrm{~kg}$, was obtained from the North Carolina State University Dairy Research and Education System. Milk was HTST pasteurized $(720 \mathrm{~kg} / \mathrm{h})$ with a plate heat exchanger (model T4 RGS-16/2, SPX Flow Technology, Greensboro, NC) at $72^{\circ} \mathrm{C}$ with a hold time of $16 \mathrm{~s}$. The milk was then cooled to $31^{\circ} \mathrm{C}$ and transferred to a cheese vat (Kusel Equipment, Watertown, WI). A standard colored Cheddar cheese-making procedure was then followed as described by Park et al. (2014a) but with the absence of annatto (norbixin) and an uncolored liquid whey was obtained. The liquid whey was passed through a sieve to remove cheese fines and HTST pasteurized under the same parameters as the milk, and fat-separated with a hot bowl centrifugal separator (model SI600E, Agri-Lac, Miami, FL).

Approximately $125 \mathrm{~kg}$ of whey was heated to $50^{\circ} \mathrm{C}$ and was concentrated with a UF system containing 10 polyethersulfone membrane cartridges (model P2B010V05, nominal cutoff $=10 \mathrm{kDa}$, surface area $=0.5 \mathrm{~m}^{2}$, Millipore Inc., Billerica, MA) and a variable-speed peristaltic pump (model P2B010V05, Cole Parmer, Vernon Hills, IL), which was used to circulate the product as a batch process. Before UF, the membrane cartridges were rinsed of their storage solution $(1 \mathrm{~N} \mathrm{NaOH})$ and a clean water flux was conducted and was typically about $35 \mathrm{~L} / \mathrm{h}$. A concentration factor of $5 \times$ and $34 \%$ protein of solids (wt/vol) was achieved and then diafiltration (DF) water was added. Deionized (DI) water was added to equal the original weight of the feed whey, followed by concentration to a solids content of $80 \%$ (wt/ wt) of protein to produce liquid WPC 80. Total solids were measured by a rapid moisture analyzer (Smart Trac II, CEM Corp., Matthews, NC) and protein was measured with a mid-infrared analyzer during processing to monitor progress (Lactoscope model FTA, Delta Instruments, Drachten, the Netherlands). 


\section{WPI Production}

Raw whole milk, $455 \mathrm{~kg}$, was pasteurized and uncolored Cheddar whey was obtained as previously described. Whey was microfiltered using a pilot-scale membrane system (Model Lab 46, Filtration Engineering, Champlin, MN). Fat was removed from the whey by two $800,000-\mathrm{Da}$ spiral-wound microfiltration (MF) membranes (Synder, Vacaville, CA; nominal cutoff: $800,000 \mathrm{Da}$, surface area $7.15 \mathrm{~m}^{2}$ ) running at $0.14 \mathrm{MPa}$ transmembrane pressure. Temperature for MF was $50^{\circ} \mathrm{C}$. The MF run time was approximately $1 \mathrm{~h}$. The MF permeate was collected and used for UF. The MF permeate was concentrated via a plate UF system as described above, to a protein percentage of $34 \%$, and DF was done by adding DI water to dilute the protein concentrate to the original whey weight and then concentrated using a UF membrane system as described above to a target composition of $90 \%$ protein (wt/wt). The UF run time was approximately $3 \mathrm{~h}$.

\section{MPC 85 Production}

Two hundred kilograms of raw skim milk was pasteurized as previously described. The milk was heated to $50^{\circ} \mathrm{C}$ and was concentrated with a UF system Millipore plate system as described above. A concentration factor of $5 \times$ and $74 \%$ protein of solids (wt/vol) was achieved and then DF water was added to equal the original weight of the feed milk, followed by concentration to of $85 \%$ (wt/wt) of protein on a solids basis to produce liquid MPC 85. Total solids were measured by a rapid moisture analyzer (Smart Trac II, CEM Corp., Matthews, NC), and protein was measured with a mid-infrared analyzer (Delta Instruments, Model FTA, Drachten, the Netherlands) during processing to monitor progress.

\section{Production}

Raw skim milk (475 kg) was pasteurized as described above. The milk was heated to $50^{\circ} \mathrm{C}$ with a plate heat exchanger and microfiltered using a pilot-scale ceramic microfiltration system (Tetra Alcross M7, TetraPak Filtration Systems, Aarhus, Denmark) in bleed-andfeed mode to continuously produce a $3 \times$ MF retentate and $\mathrm{MF}$ permeate at $50^{\circ} \mathrm{C}$ as described by Zulewska et al. (2009) with slight modifications. As opposed to a uniform transmembrane pressure membrane, a 0.1 $\mu \mathrm{m}$ graded permeability membrane was used, which does not require the use of a permeate recirculation pump. After the first stage, the MF retentate was diluted back to a $1 \times$ concentration $(2 \mathrm{~kg}$ of water for every $1 \mathrm{~kg}$ of retentate) with DI water, heated to $50^{\circ} \mathrm{C}$, and diafiltered with the ceramic MF system to produce a $3 \times$ retentate, then this diafiltration procedure was repeated to complete a 3 -stage process. This produced a $95 \%$ serum protein reduced MCC.

\section{Liquid Sampling}

Liquid samples of each protein $(1.5 \mathrm{~L})$ were collected after the UF or MF. Samples were collected in plastic milk jugs and quickly cooled in an ice bath to $4^{\circ} \mathrm{C}$. Samples were stored at $3^{\circ} \mathrm{C}$. Sensory and functionality tests as well as volatile compound analysis were conducted within $24 \mathrm{~h}$ of protein manufacture.

\section{Spray Drying}

The remaining liquid retentate of each protein was dried in a spray dryer (model Lab 1, Anhydro Inc.) with an inlet temperature of $210^{\circ} \mathrm{C}$ and an outlet temperature of $90^{\circ} \mathrm{C}$ and a feed solids of 10 to $14 \%$. The dried protein powders were collected in Mylar bags (TF-4000, Impak Corp.), flushed with nitrogen, and stored at $-80^{\circ} \mathrm{C}$ until analyses.

\section{Gas Chromatography/Mass Spectrometry}

Volatile compounds were extracted from the different protein sources by SPME following the method used by Campbell et al. (2011) with modifications. Each protein was rehydrated to $10 \%$ solids (wt/vol) using UPLC-grade water (Fisher Chemicals Inc., Waltham, $\mathrm{MA}$ ), and $5 \mathrm{~mL}$ was added to 20-mL SPME vials (MicroLiter Analytical Supplies Inc., Suwanee, GA) along with $10 \%$ (wt/vol) salt in triplicate (Campbell et al., 2011). Samples were placed into 20-mL auto sampler vials with steel screw tops containing silicone septa faced in Teflon (MicroLiter Analytical Supplies Inc.). Ten microliters of $81 \mathrm{mg} / \mathrm{kg}$ 2-methyl-3-heptanone in methanol (Sigma-Aldrich) was added as an internal standard. Samples were injected by a CombiPal autosampler (CTC Analytics, Zwingen, Switzerland) into an Agilent 6890N GC with 5973 inert MSD (Agilent Technologies Inc.). Samples were held at $10^{\circ} \mathrm{C}$ before fiber exposure and brought up to $40^{\circ} \mathrm{C}$ for $25 \mathrm{~min}$ before $30 \mathrm{~min}$ of fiber exposure of a 1-cm divinyl-benzene/ carboxen/polydimethylsiloxane fiber at $31 \mathrm{~mm}$ with $4 \mathrm{~s}$ of pulsed agitation at $250 \mathrm{rpm}$. The fibers were injected for $5 \mathrm{~min}$ at a depth of $50 \mathrm{~mm}$. The GC method used a start temperature of $40^{\circ} \mathrm{C}$ for 3 min with a gradual increase of $10^{\circ} \mathrm{C} / \mathrm{min}$ until $250^{\circ} \mathrm{C}$ was reached. The sample was then held for $5 \mathrm{~min}$. The column used was a Zb-5ms (Zb-5ms, $30 \mathrm{~m}$ length $\times 0.25 \mathrm{~mm}$ inner diameter $\times 0.25 \mu \mathrm{m}$ film thickness; Phenomenex) with a constant flow rate of $1 \mathrm{~mL} / \mathrm{min}$ in SIM and SCAN 
mode. Purge time was $1 \mathrm{~min}$. Compounds evaluated included components identified in previous studies to be crucial to ingredient flavor (Whetstine et al., 2003, 2005; Drake et al., 2009; Croissant et al., 2009; Whitson et al., 2010; Smith et al., 2016b,c; Park et al., 2016b) Compounds were identified using the National Institute of Standards and Technology (2002, Gaithersburg, MD) mass spectral database and comparison of mass spectra of authentic standards. Retention indexes were calculated using an alkane series (Sigma-Aldrich). The internal standard concentration was used to calculate the relative abundance of each compound.

\section{Descriptive Sensory Analysis}

Descriptive sensory analysis was conducted in compliance with North Carolina State University Institutional Review Board for Human Subjects guidelines. Samples were rehydrated (powder or diluted liquids) to $10 \%$ solids (wt/vol) and dispensed into 59-mL cups with lids (Solo Cup Co., Champaign, IL) labeled with 3 -digit codes. Eight panelists (23-45 yr old, 2 females, 6 males), each with more than $100 \mathrm{~h}$ of experience with descriptive analysis of dried dairy ingredients and the Spectrum 0 to 15 point universal scale (Meilgaard et al., 2007), evaluated the samples using established sensory languages (Wright et al., 2009; Smith et al., 2016a). Each sample was evaluated by each panelist in duplicate. Compusense Cloud (Compusense, Guelph, Canada) was used for data collection.

\section{Proximate Analysis}

Percent moisture of powders was measured using a vacuum oven (AOAC International, 2000; method 990.20; 33.2.44). The total fat content of powders was measured by reconstituting the powder in water $\left(38^{\circ} \mathrm{C}\right)$ to a concentration similar to the liquid samples, cooled to $4^{\circ} \mathrm{C}$, and held overnight for rehydration before chemical analysis then analyzed by ether extraction (AOAC International, 2000; method 989.05; 33.2.26). Total protein of powders was measured using the Kjeldahl method (AOAC International, 2000; method 991.20; 33.2.11) by multiplying total nitrogen by a factor of 6.38 .

\section{Foam Generation}

An Artisan KitchenAid Mixer (KitchenAid, St. Joseph, MI) with a 4.5-quart stationary bowl and a rotating wire beater was used to generate the protein foams as described by Smith et al. (2016c). Solutions (10\% solids wt/vol) of each powder protein was rehydrated for $6 \mathrm{~h}$ at room temperature $\left(21^{\circ} \mathrm{C}\right)$ on a stir plate and refrigerated overnight at $4^{\circ} \mathrm{C}$. Before foaming, the temperature of rehydrated powders and diluted liquids solutions $\left(10 \%\right.$ solids wt/vol) was brought to $21^{\circ} \mathrm{C}$ and $\mathrm{pH}$ adjusted to 7 using $1 \mathrm{~N} \mathrm{NaOH}$ (VWR International). Each solution $(200 \mathrm{~mL})$ was whipped at speed 8 (planetary rpm of 225 and beater rpm of 737) for 20 min (Davis and Foegeding, 2007). Foams were prepared in triplicate from each liquid or powder.

\section{Yield Stress}

A Brookfield 25xLVTDV-CIP viscometer (Brookfield Engineering Laboratories Inc., Middleboro, MA) was used to test yield stress of foams produced using vane rheometry (Pernell et al., 2000; Davis and Foegeding, 2007). Tests were conducted at a speed of $0.3 \mathrm{rpm}$ with a vane diameter of 10 and $40 \mathrm{~mm}$ length. Maximum torque response $\left(M_{o}\right)$ was determined in each sample in triplicate. $\mathrm{M}_{\mathrm{o}}$ was converted to yield stress using the following formula (Dzuy and Boger 1983, 1985; Steffe, 1996):

$$
\mathrm{T}_{\mathrm{o}}=\mathrm{M}_{\mathrm{o}} /[(\mathrm{h} / \mathrm{d})+(1 / 6)]\left[\left(\pi \mathrm{d}^{3}\right) / 2\right],
$$

where $T_{o}$ is yield stress and $h$ and $d$ are the height and diameter of the vane, respectively. Torque measurements were taken in triplicate.

\section{Overrun}

Overrun of the foams was determined after yield stress of the foams was determined. Foam was removed from the mixing bowl with a rubber spatula and placed into a 100-mL weighing dish in triplicate. Overrun and air phase fraction were determined using the following formulas:

$$
\begin{gathered}
\text { Overrun }=[(\text { wt of } 100 \mathrm{~mL} \text { of solution }) \\
-(\text { wt of } 100 \mathrm{~mL} \text { of foam }) / \text { wt of } 100 \mathrm{~mL} \text { of foam }] \\
\times 100 .
\end{gathered}
$$

Air phase fraction $(\Phi)=$ $\%$ overrun $/(\%$ overrun +100$)$.

Treatments were measured in triplicate (Dickinson, 1999; Wilde, 2000; Davis and Foegeding, 2007).

\section{Foam Stability}

Foam stability was determined by measuring the time necessary for half of the prefoam mass to drain through a hole in the whipping bowl (Phillips et al., 
1990; Luck et al., 2001). Starting time for the measurements began immediately after foam formation (Davis and Foegeding, 2007).

\section{Heat Stability}

Solutions ( $10 \%$ solids) of each powder were made by rehydrating the protein powder for $6 \mathrm{~h}$ at room temperature $\left(21^{\circ} \mathrm{C}\right)$ on a stir plate set to $200 \mathrm{rpm}$ (Campbell et al., 2011) or diluting the liquid retentates to $80 \%$ of the desired volume such that the final targeted volume was $10 \%$ solids (wt/vol). Solutions were then held overnight at $4^{\circ} \mathrm{C}$. After bringing the temperature to $21^{\circ} \mathrm{C}$ the next day, the solutions were adjusted to a pH of 7 using $1 \mathrm{~N} \mathrm{NaOH}$, after which each solution was brought to a total volume of $100 \mathrm{~mL}$ with DI water (a final solids of $10 \% \mathrm{wt} / \mathrm{vol}$ ). Heat stability was measured using the methods described by Jervis et al. (2012). The solutions were then heated in a water bath at $90^{\circ} \mathrm{C}$ for 0,10 , and $20 \mathrm{~min}$ and then placed in an ice bath until reaching an internal temperature of $21^{\circ} \mathrm{C}$. Turbidity and micro-bicinchoninic acid (BCA) measurements were then taken before and after centrifugation. Turbidity and solubility using micro-BCA assay (described below) were performed on the heated solutions after which they were centrifuged at $10,000 \times g$ for $10 \mathrm{~min}$ at $21^{\circ} \mathrm{C}$ (model RC5B centrifuge, Thermo Scientific), and the turbidity and solubility were performed again on the supernatants.

Solutions were diluted 1:100 in DI water and added at a ratio of $1: 8$ to a working reagent consisting of Pierce BCA Protein Assay Reagent A 50 parts to 1 part Reagent B (Thermo Scientific), and pipetted into a 96-well plastic plate. Micro-BCA was performed in triplicate. The plate was placed on a shaker for $30 \mathrm{~s}$ and incubated at $37^{\circ} \mathrm{C}$ for $30 \mathrm{~min}$. The plate was allowed to return to room temperature and read on a Tecan Safire plate reader spectrophotometer at wavelength $562 \mathrm{~nm}$ (Tecan, Durham, NC). Soluble protein after heat treatment was calculated using the following equation (Abs = absorbance):

$$
\begin{gathered}
\text { protein solubility }= \\
100-\left\{\left[\left(\mathrm{Abs}_{\text {before }}-\mathrm{Abs}_{\text {after }}\right) / \mathrm{Abs}_{\text {before }}\right] \times 100\right\} .
\end{gathered}
$$

Analyses were performed in triplicate.

\section{Statistical Analysis}

Data were analyzed using XLSTAT (version 2013.5.03, Addinsoft, New York, NY). An ANOVA was conducted to compare liquid and powder forms of each protein. Differences were analyzed by Tukey's honestly significant difference.

\section{RESULTS AND DISCUSSION}

\section{Proximate Analysis}

No difference was observed between the moisture content between WPC80 and WPI $(P>0.05)$, but a large difference was observed in fat content $(P<0.05$; Table 1). No difference in fat content was detected between the milk protein products (MPC 85, MCC), which was expected as they were both produced from similar lots of skim milk $(P>0.05)$. All protein percentages for each protein were within the typical range for these products. The WPC 80 had higher fat levels than other proteins $(P<0.05)$, which is of interest because previous work has shown that the fat level affects some functional properties (Jervis et al., 2012; Qiu et al., 2015).

\section{Descriptive Sensory Analysis}

Sensory properties between liquid and protein powders were distinct $(P<0.05$; Table 2$)$. Spray drying increased the aroma intensities of all the proteins $(P<$ 0.05). Cardboard flavor is a common off-flavor in liquid whey, dried whey, and milk that is a result of lipid oxidation (Wright et al., 2009; Whitson et al., 2010; Smith et al., 2016a,b). Even low intensities of this proteinassociated off-flavor are evident in finished applications and negatively affect consumer acceptance (Childs and Drake, 2010; Evans et al., 2010). Spray drying is a heat process and can change the nature of fat on the surface of particles, which could increase the rate of lipid oxidation, as shown by the increase in cardboard flavor between the liquid and dried product across all ingredi-

Table 1. Proximate analysis of proteins on a dry weight basis expressed as a percentage $( \pm \mathrm{SD})^{1}$

\begin{tabular}{lrrrr}
\hline Item & WPC 80 & \multicolumn{1}{c}{ WPI } & MPC 85 & \multicolumn{1}{c}{ MCC } \\
\hline Moisture & $3.45 \pm 0.48^{\mathrm{b}}$ & $3.46 \pm 0.25^{\mathrm{b}}$ & $3.94 \pm 0.79^{\mathrm{b}}$ & $5.10 \pm 0.59^{\mathrm{a}}$ \\
Protein & $81.13 \pm 0.36^{\mathrm{c}}$ & $90.51 \pm 1.81^{\mathrm{a}}$ & $84.05 \pm 0.87^{\mathrm{b}}$ & $82.26 \pm 0.57^{\mathrm{bc}}$ \\
Fat & $6.32 \pm 0.35^{\mathrm{a}}$ & $0.48 \pm 0.07^{\mathrm{c}}$ & $1.60 \pm 0.14^{\mathrm{b}}$ & $1.60 \pm 0.06^{\mathrm{b}}$ \\
\hline
\end{tabular}

${ }^{a-c}$ Means in the same row not sharing common letters are different $(P<0.05)$.

${ }^{1} \mathrm{WPC} 80=$ whey protein concentrate with $80 \%$ protein; WPI $=$ whey protein isolate; MPC $85=$ milk protein concentrate with $85 \%$ protein; $\mathrm{MCC}=$ micellar casein concentrate. 
Table 2. Sensory profiles (attributes on a 0 to 15 point scale) of liquid and dried proteins ${ }^{1}$

\begin{tabular}{|c|c|c|c|c|c|c|c|}
\hline Item & & $\begin{array}{c}\text { Aroma } \\
\text { intensity }\end{array}$ & $\begin{array}{c}\text { Sweet } \\
\text { aromatic }\end{array}$ & Cardboard & $\begin{array}{c}\text { Cooked } \\
\text { milky }\end{array}$ & $\begin{array}{l}\text { Corn chip/ } \\
\text { tortilla }\end{array}$ & Astringency \\
\hline \multirow[t]{2}{*}{ WPC 80} & Liquid & $\begin{array}{l}0.6^{\mathrm{b}} \\
(0.2)\end{array}$ & $\begin{array}{c}0.6^{\mathrm{b}} \\
(0.2)\end{array}$ & $\begin{array}{c}0.6^{\mathrm{b}} \\
(0.2)\end{array}$ & ND & $\mathrm{ND}$ & $\begin{array}{l}1.7^{\mathrm{b}} \\
(0.3)\end{array}$ \\
\hline & Powder & $\begin{array}{l}1.5^{\mathrm{a}} \\
(0.3)\end{array}$ & $\begin{array}{r}0.9^{\mathrm{a}} \\
(0.3)\end{array}$ & $\begin{array}{l}1.3^{\mathrm{a}} \\
(0.2)\end{array}$ & ND & ND & $\begin{array}{l}2.3^{\mathrm{a}} \\
(0.3)\end{array}$ \\
\hline \multirow[t]{2}{*}{ WPI } & Liquid & $\begin{array}{r}0.5^{\mathrm{b}} \\
(0.2)\end{array}$ & ND & $\begin{array}{r}0.9^{b} \\
(0.3)\end{array}$ & ND & ND & $\begin{array}{r}1.7^{\mathrm{a}} \\
(0.4)\end{array}$ \\
\hline & Powder & $\begin{array}{l}1.4^{\mathrm{a}} \\
(0.3)\end{array}$ & $\begin{array}{c}0.9 \\
(0.3)\end{array}$ & $\begin{array}{l}1.5^{\mathrm{a}} \\
(0.3)\end{array}$ & ND & ND & $\begin{array}{l}1.6^{\mathrm{a}} \\
(0.3)\end{array}$ \\
\hline \multirow[t]{2}{*}{ MPC 85} & Liquid & $\begin{array}{r}0.7^{b} \\
(0.3)\end{array}$ & $\begin{array}{r}0.6^{\mathrm{a}} \\
(0.2)\end{array}$ & $\begin{array}{l}0.5^{b} \\
(0.2)\end{array}$ & $\begin{array}{r}3.0^{\mathrm{b}} \\
(0.2)\end{array}$ & ND & $\begin{array}{l}2.5^{\mathrm{a}} \\
(0.3)\end{array}$ \\
\hline & Powder & $\begin{array}{l}1.9^{\mathrm{a}} \\
(0.3)\end{array}$ & $\begin{array}{r}0.7^{\mathrm{a}} \\
(0.2)\end{array}$ & $\begin{array}{l}1.4^{\mathrm{a}} \\
(0.3)\end{array}$ & $\begin{array}{r}3.4^{\mathrm{a}} \\
(0.3)\end{array}$ & ND & $\begin{array}{l}2.7^{\mathrm{a}} \\
(0.3)\end{array}$ \\
\hline \multirow[t]{2}{*}{$\mathrm{MCC}$} & Liquid & $\begin{array}{r}0.5^{b} \\
(0.2)\end{array}$ & $\begin{array}{r}0.7^{\mathrm{a}} \\
(0.2)\end{array}$ & ND & $\begin{array}{r}3.2^{\mathrm{a}} \\
(0.4)\end{array}$ & ND & $\begin{array}{r}3.5^{\mathrm{a}} \\
(0.3)\end{array}$ \\
\hline & Powder & $\begin{array}{l}1.7^{\mathrm{a}} \\
(0.3)\end{array}$ & $\begin{array}{r}0.8^{\mathrm{a}} \\
(0.2)\end{array}$ & $\begin{array}{c}1.2 \\
(0.2)\end{array}$ & $\begin{array}{c}3.4^{\mathrm{a}} \\
(0.3)\end{array}$ & $\begin{array}{c}1.4 \\
(0.2)\end{array}$ & $\begin{array}{r}3.5^{\mathrm{a}} \\
(0.4)\end{array}$ \\
\hline
\end{tabular}

${ }^{\mathrm{a}, \mathrm{b}}$ Means in a column not sharing common superscripts within a protein type are different $(P<0.05)$.

${ }^{1} \mathrm{WPC} 80=$ whey protein concentrate with $80 \%$ protein; WPI $=$ whey protein isolate; MPC $85=$ milk protein concentrate with $85 \%$ protein; $\mathrm{MCC}=$ micellar casein concentrate. The SD is provided below each mean in parentheses. ND = not detected. Comparison for significance is made between liquid and powder of each protein and not in between the different proteins.

ents. Increased fat content in dried protein ingredients does not correlate with increased relative abundance of lipid oxidation compounds (Jervis et al., 2012) and this is consistent with comparison of WPC 80 and WPI in the present study (Table 2).

Park et al. (2014a) showed that aldehydes can bind to proteins during the spray-drying process. Many of these aldehydes at neutral $\mathrm{pH}$, particularly hexanal, instead of volatizing and exiting into the air phase bind and remain attached to the protein and impart increased cardboard flavor in the powder. Spray-drying parameters can also affect the surface free fat of WPC (Park et al., 2014b). Changing spray dryer parameters changes the particles size of the dried protein particles. A larger protein particle has lower amounts of surface free fat due to the lower ratio of surface area to internal volume of the particles. Increased surface free fat correlates with increased levels of lipid oxidation compounds. This concept was also demonstrated in MPC 70 (Park et al., 2016a). Spray dried MCC had a distinct corn chip flavor that was not detected in liquid MCC. This flavor has been previously noted in dried milk proteins and has been associated with 2-aminoacetophenone (Drake et al., 2009; Smith et al., 2016a,b). Evans et al. (2009) compared the sensory profiles of freeze-dried and spray-dried $34 \%$ serum and whey protein concentrates but did not evaluate liquids. The current study is the first to our knowledge to address the specific role of spray drying on the flavor of a range of milk and whey proteins. Across all proteins evaluated in the study, the process of spray drying increased aroma and specific flavor intensities.

\section{Volatile Compound Analysis}

Flavors in liquid whey can be classified into one of the following groups: dairy or nondairy flavors (Whetstine et al., 2005; Drake, 2006). Dairy flavors are those that are associated with fresh fluid milk or whey such as sweet aromatic and cooked/milky flavors and are often desirable (Whetstine et al., 2005). Nondairy flavors are those that are not generally associated with fresh fluid milk or whey, are undesirable, and include cardboard and corn chip/tortilla flavors among others (Whetstine et al., 2005; Drake et al., 2009; Smith et al., 2016a). Nondairy flavors are often undesirable and volatile compound analysis can be used to correlate flavor attributes with specific flavor compounds to help identify the source and develop methods of prevention or removal of the compound. Flavor variability can come from a variety of sources and different processing conditions (Whetstine et al., 2003; Drake et al., 2009; Park et al., 2014b, 2016a,b; Smith et al., 2016a,b).

Spray dried powders were characterized by higher relative abundances of hexanal, Z-2-heptenal, octanal, 2-nonenal, E-2-nonenal, pentanal, 2-methyl butanal, 1-octen-3-one $(P<0.05)$ compared with liquid counterparts (Table 3 ). These compounds have been identified in whey and milk protein products previously and are correlated with protein degradation as well as lipid oxidation and cardboard flavor (Wright et al., 2006; Croissant et al., 2009; Evans et al., 2009; Whitson et al., 2010; Listiyani et al., 2011; Jervis et al., 2012; Park et al., 2016a; Smith et al., 2016b). These volatile compound profiles are consistent with descriptive sensory 
CARTER ET AL.

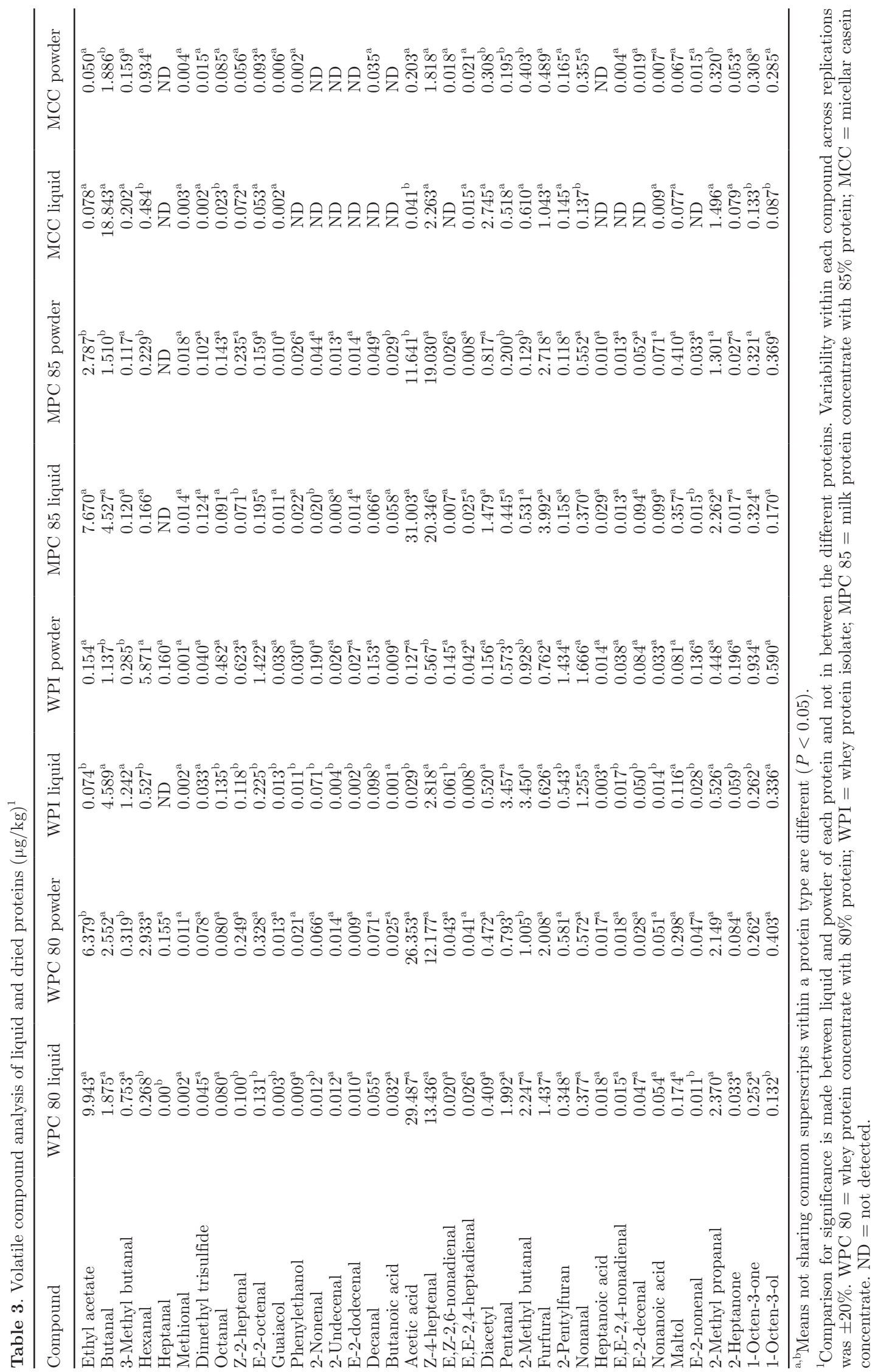




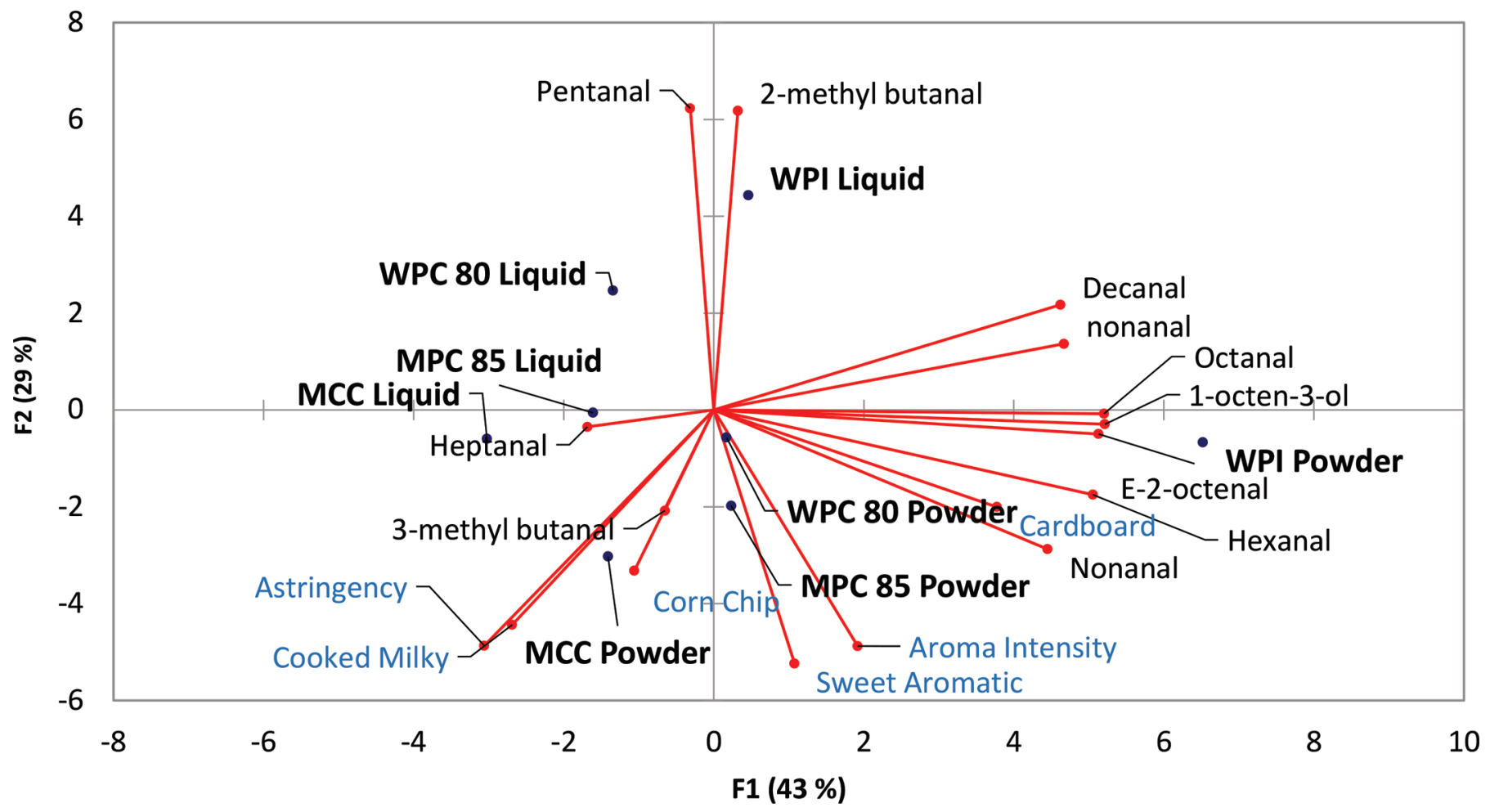

Figure 1. Principal component biplot of selected volatile compounds and sensory attributes. WPC $=$ whey protein concentrate; WPI $=$ whey protein isolate; $\mathrm{MPC}=$ milk protein concentrate; $\mathrm{MCC}=$ micellar casein concentrate; numbers indicate percentage of protein. Color version available online.

results and again show that spray drying has detrimental effects on flavor (Figure 1).

\section{Functionality}

All proteins produced a foam except for WPC 80 (Table 4). This result is consistent with previous research that demonstrated that WPC 80 did not produce a foam, most likely due to the fat content (Jervis et al., 2012; Qiu et al., 2015). It has also been proposed that other antifoam agents exist or are created in whey during processing and cheesemaking (de la Fuente et al., 2002). All other proteins produced foams with no statistical difference detected between liquid and powder samples in foam stability and yield stress $(P>0.05)$. The MCC produced higher overrun and better foam stability than MPC, which might be of some interest in different ingredient applications.

A difference $(P<0.05)$ was observed in the overrun and air phase fraction between liquid and powder in

Table 4. Functional properties of liquid and dried proteins ${ }^{1}$

\begin{tabular}{|c|c|c|c|c|c|c|}
\hline \multirow[b]{2}{*}{ Item } & \multicolumn{2}{|c|}{ WPI } & \multicolumn{2}{|c|}{ MPC 85} & \multicolumn{2}{|c|}{ MCC } \\
\hline & Liquid & Powder & Liquid & Powder & Liquid & Powder \\
\hline$\overline{\text { Overrun }(\%)}$ & $\begin{array}{l}762^{\mathrm{b}} \\
(22)\end{array}$ & $\begin{array}{r}852^{\mathrm{a}} \\
(34)\end{array}$ & $\begin{array}{l}671^{\mathrm{a}} \\
(41)\end{array}$ & $\begin{array}{c}615^{\mathrm{a}} \\
(35)\end{array}$ & $\begin{array}{l}957^{\mathrm{a}} \\
(47)\end{array}$ & $\begin{array}{c}623^{\mathrm{b}} \\
(53)\end{array}$ \\
\hline Air phase fraction (\%) & $\begin{array}{r}92.9^{\mathrm{a}} \\
(0.3)\end{array}$ & $\begin{array}{c}92.1^{\mathrm{b}} \\
(0.2)\end{array}$ & $\begin{array}{r}93.7^{\mathrm{a}} \\
(0.4)\end{array}$ & $\begin{array}{r}94.2^{\mathrm{a}} \\
(0.6)\end{array}$ & $\begin{array}{l}91.1^{\mathrm{a}} \\
(0.8)\end{array}$ & $\begin{array}{c}93.1^{\mathrm{b}} \\
(0.4)\end{array}$ \\
\hline Foam stability (min) & $\begin{array}{c}25.77^{\mathrm{a}} \\
(1.2)\end{array}$ & $\begin{array}{c}27.42^{\mathrm{a}} \\
(0.9)\end{array}$ & $\begin{array}{r}9.1^{\mathrm{a}} \\
(0.5)\end{array}$ & $\begin{array}{r}9.6^{\mathrm{a}} \\
(0.3)\end{array}$ & $\begin{array}{l}43.37^{\mathrm{a}} \\
(14)\end{array}$ & $\begin{array}{l}23.36^{\mathrm{a}} \\
(11)\end{array}$ \\
\hline
\end{tabular}

${ }_{\mathrm{a}, \mathrm{b}}$ Means not sharing common superscripts within a protein type are different $(P<0.05)$.

${ }^{1} \mathrm{WPI}=$ whey protein isolate; MPC $85=$ milk protein concentrate with $85 \%$ protein; MCC $=$ micellar casein concentrate. Whey protein concentrate with $80 \%$ protein is not shown because it produced no foam. The SD is provided below each mean in parentheses. 
WPI and MCC. In WPI, the overrun and air phases were greater in powder compared with the liquid. This is most likely due to the relative low heat stability of whey proteins that resulted in greater heat denaturation during spray drying. No difference was found between liquid and powder samples for heat stability $(P>0.05)$ (results not shown). The proteins, both liquid and powder, followed expected trends of heat stability (Jervis et al., 2012; Smith et al., 2016b,c). Whey protein (WPC 80 , WPI) solubility decreased greatly after $10 \mathrm{~min}$ of heating and formed a gel, of which the supernatant had little soluble protein. The milk proteins were more heat stable, and there was no difference between liquids and powders.

\section{CONCLUSIONS}

This study was conducted to better understand how spray drying affects flavor and functional properties of a range of common protein products. Spray drying under the conditions used in this study had little effect on the functional properties of the protein. Flavor of the different protein products was affected by spray drying. Spray drying caused increased levels of cardboard flavor and a higher aroma intensity than observed in the liquid concentrates before drying, concurrent with increased concentrations of several neutral aldehydes. Additionally, in MCC, spray drying created an undesirable corn chip flavor. The improved flavor of liquid protein retentates provides opportunities to have lower protein related off-flavors in formulated food and beverage products. The use of liquid in place of powder also has the potential to save on expensive upkeep and operation of drying units as well as increased protein yields. The use of liquid retentates will also avoid the trouble of rehydrating protein powders and avoid the issues that ensue with a poorly hydrated powder. Beverage and food formulators can replace powder protein with liquid concentrates and expect similar functional properties and improved, blander flavor.

\section{ACKNOWLEDGMENTS}

Funding was provided in part by the National Dairy Council (Rosemont, IL). The use of tradenames does not indicate endorsement or indicate a lack of endorsement by those not mentioned.

\section{REFERENCES}

Agarwal, S., R. L. W. Beausire, S. Patel, and H. Patel. 2015. Innovative uses of milk protein concentrates in product development. J. Food Sci. 80:A23-A29.

AOAC International. 2000. Official Methods of Analysis. 17th ed. Association of Official Analytical Chemists, Gaithersburg, MD.
Augustin, M. A., and P. Udabage. 2007. Influence of processing on functionality of milk and dairy proteins. Adv. Food Nutr. Res. $53: 1-38$.

Beckman, S., J. Zulewska, M. Newbold, and D. M. Barbano. 2010. Production efficiency of a micellar casein concentrate using spiralwound microfiltration membranes. J. Dairy Sci. 93:4506-4517.

Campbell, R. E., R. E. Miracle, P. Gerard, and M. A. Drake. 2011. Effects of starter culture and storage on the flavor of liquid whey. J. Food Sci. 76:S354-S361.

Caudle, A. D., Y. Yoon, and M. A. Drake. 2005. Influence of flavor variability in skim milk powder on consumer acceptability of ingredient applications. J. Food Sci. 70:S427-S431.

Childs, J. L., and M. A. Drake. 2010. Consumer perception of astringency in acidic whey protein beverages. J. Food Sci. 75:S513-S521.

Childs, J. L., M. D. Yates, and M. A. Drake. 2007. Sensory properties of meal replacement bars and beverages made from soy and whey proteins. J. Food Sci. 72:S425-S434.

Croissant, A. E., E. J. Kang, R. E. Campbell, E. Bastian, and M. A Drake. 2009. The effect of bleaching agent on the flavor of liquid whey and whey protein concentrate. J. Dairy Sci. 92:5917-5927.

Davis, J. P., and E. A. Foegeding. 2007. Comparisons of the foaming and interfacial properties of whey protein isolate and egg white proteins colloids and surfaces. Colloids Surf. B Biointerfaces 54:200-210.

de la Fuente, M. A., Y. Hemar, M. Tamehana, P. A. Munro, and H. Singh. 2002. Process induced changes in whey proteins during the manufacture of whey protein concentrates. Int. Dairy J. $12: 361-369$.

de Wit, J. N. 1998. Nutritional and functional characteristics of whey proteins in food products. J. Dairy Sci. 81:597-608.

Dickinson, E. 1999. Adsorbed protein layers at fluid interfaces: Interactions, structure and surface rheology. Colloid Surf. Biointerf. 15:161-176.

Drake, M. A. 2006. Flavor and flavor carry-through of whey proteins in beverages. Page 292-300 in The Wonders of Whey ... Catch the Power. Proceedings of the 4th International Whey Conference. American Dairy Products Institute, Elmhurst, IL.

Drake, M. A., R. E. Miracle, and J. M. Wright. 2009. Sensory properties of dairy proteins. Pages 429-448 in Milk Proteins: From Expression to Food. A. Thompson, M. Boland, and H. Singh, ed. Elsevier, Amsterdam, the Netherlands.

Dzuy, M. Q., and D. V. Boger. 1983. Yield stress measurement for concentrated suspensions. J. Rheol. (N.Y.N.Y.) 27:321-349.

Dzuy, M. Q., and D. V. Boger. 1985. Direct yield stress measurement with the vane method. J. Rheol. (N.Y.N.Y.) 29:335-347.

Evans, J. P., J. Zulewska, M. Newbold, M. A. Drake, and D. M. Barbano. 2009. Comparison of composition, sensory and volatile components of thirty four percent whey protein and serum protein concentrates. J. Dairy Sci. 92:4773-4791.

Evans, J. P., J. Zulewska, M. Newbold, M. A. Drake, and D. M. Barbano. 2010. Comparison of composition and sensory properties of $80 \%$ whey protein and milk serum protein concentrates. J. Dairy Sci. 93:1824-1843.

Fang, Y., S. Rogers, C. Selomulya, and X. D. Chen. 2012. Functionality of milk protein concentrate: Effect of spray drying temperature. Biochem. Eng. J. 62:101-105.

Gaiani, C., M. Morand, C. Sanchez, E. Arab Therany, M. Jacquot, P. Schuck, R. Jeantet, and J. Scher. 2010. How surface composition of high milk protein powders is influenced by spray drying temperature. Colloids Surf. B Biointerfaces 75:377-384.

Henning, D. R., R. J. Baer, A. N. Hassan, and R. Dave. 2006. Major advances in concentrated and dry milk products, cheese, and milk fat-based spreads. J. Dairy Sci. 89:1179-1188.

Jervis, S., R. Campbell, K. L. Wojciechowski, E. A. Foegeding, M. A. Drake, and D. M. Barbano. 2012. Effect of bleaching whey on sensory and functional properties of $80 \%$ whey protein concentrate. J. Dairy Sci. 95:2848-2862.

Lee, Y. B., and C. V. Morr. 1994. Changes of headspace volatile compounds due to oxidation of milk fat during storage of dried dairy products. Pages $98-107$ in Lipids in Food Flavors. C. T. Ho and T. G. Hartman, ed. American Chemical Society, Washington, DC. 
Listiyani, M. A. D., R. E. Campbell, R. E. Miracle, L. O. Dean, and M. A. Drake. 2011. Influence of bleaching on the flavor of $34 \%$ whey protein concentrate and residual benzoic acid concentration in dried whey proteins. J. Dairy Sci. 94:4347-4359.

Luck, P. J., N. Bray, and E. A. Foegeding. 2001. Factors determining yield stress and overrun of whey protein foams. J. Food Sci. 67:1677-1681.

Meilgaard, M. C., G. V. Civille, and B. T. Carr. 2007. The Spectrum ${ }^{\mathrm{TM}}$ descriptive analysis method. Pages 189-253 in Sensory Evaluation Techniques. CRC Press, Boca Raton, FL.

Morr, C. V., and E. Y. W. Ha. 1991. Off-flavors of whey protein concentrates: A literature review. Int. Dairy J. 1:1-11.

Nikolova, Y., J. Petit, A. Gianfrancesco, C. F. W. Sanders, J. Scher, and C. Gaiani. 2015. Impact of spray-drying process parameters on dairy powder surface composition and properties. Dry. Technol. 33:1654-1661.

Ozmen, L., and T. G. Langrish. 2003. An experimental investigation of the wall deposition of milk powder in a pilot-scale spray dryer. Dry. Technol. 21:1253-1272.

Park, C. W., E. Bastian, B. Farkas, and M. A. Drake. 2014a. The effect of acidification of liquid why protein concentrate on the flavor of spray-dried powder. J. Dairy Sci. 97:4043-4051.

Park, C. W., E. Bastian, B. Farkas, and M. A. Drake. 2014b. The effect of feed solids concentration and inlet temperature on the flavor of spray dried whey protein concentrate. J. Food Sci. 79:C19-C24.

Park, C. W., and M. A. Drake. 2016. Condensed milk storage and evaporation affect the flavor of nonfat dry milk. J. Dairy Sci. 99:9586-9597.

Park, C. W., M. Parker, and M. A. Drake. 2016b. The effect of liquid storage on the flavor of whey protein concentrate. J. Dairy Sci. 99:4303-4308.

Park, C. W., M. A. Stout, and M. A. Drake. 2016a. The effect of spray-drying parameters on the flavor of nonfat dry milk and milk protein concentrate 70\%. J. Dairy Sci. 99:9598-9610.

Pernell, C. W., E. A. Foegeding, and C. R. Daubert. 2000. Measurement of the yield stress of protein foams by vane rheometry. J. Food Sci. 65:110-114.

Phillips, L. G., J. B. German, T. E. O'Neill, E. A. Foegeding, V. R Harwalkar, A. Kilara, B. A. Lewis, M. E. Mangino, C. V. Morr, J. M. Regenstein, D. M. Smith, and J. E. Kinsella. 1990. Standardized procedure for measuring foaming properties of three proteins, a collaborative study. J. Food Sci. 55:1441-1444.

Qiu, Y., T. J. Smith, E. A. Foegeding, and M. A. Drake. 2015. The effect of microfiltration on color, flavor, and functionality of $80 \%$ whey protein concentrate. J. Dairy Sci. 98:5862-5873.

Schuck, P., C. Floch-Fouere, and R. Jeantet. 2013. Changes in functional properties of milk protein powders: Effects of vacuum concentration and drying. Dry. Technol. 31:1578-1591.
Smith, T. J., R. E. Campbell, and M. A. Drake. 2016a. Sensory properties of milk protein ingredients. Pages 197-223 in Advanced Dairy Chemistry, Volume 1B: Proteins: Applied Aspects. P. L. H. McSweeney and P. F. Fox, ed. Springer, New York, NY.

Smith, T. J., R. E. Campbell, Y. Jo, and M. A. Drake. 2016b. Flavor and stability of milk proteins. J. Dairy Sci. 99:4325-4346.

Smith, T. J., E. A. Foegeding, and M. A. Drake. 2016c. Flavor and functional characteristics of whey protein isolates from different whey sources. J. Food Sci. 81:C849-C857.

Steffe, J. F. 1996. Rheological Methods in Food Process Engineering. 2nd ed. Freeman Press, East Lansing, MI.

Tunick, M. H. 2008. Whey protein production and utilization: A brief history. Chapter I in Whey Processing, Functionality, and Health Benefits. C. I. Onwulata and P. J. Huth, ed. Wiley-Blackwell, Ames, IA.

Uluko, H., L. Liu, J. Lv, and S. Zhang. 2016. Functional characteristics of milk protein concentrates and their modification. Crit. Rev. Food Sci. Nutr. 56:1193-1208.

US Dairy Export Council. 2004. Reference Manual for US Whey and Lactose Products. Online. Accessed Feb. 13, 2018. http://usdec .org/files/pdfs/us08D_04.pdf.

Whetstine, M. E., A. E. Croissant, and M. A. Drake. 2005. Characterization of dried whey protein concentrate and isolate flavor. J. Dairy Sci. 88:3826-3839.

Whetstine, M. E., J. D. Parker, M. A. Drake, and D. K. Larick. 2003. Determining flavor and flavor variability in commercially produced liquid Cheddar whey. J. Dairy Sci. 86:439-448.

White, S. S., K. M. Fox, S. M. Jervis, and M. A. Drake. 2013. Influence of heating and acidification on the flavor of whey protein isolate. J. Dairy Sci. 96:1366-1379.

Whitson, M. E., R. E. Miracle, and M. A. Drake. 2010. Sensory characterization of chemical components responsible for cardboard flavor in whey proteins. J. Sens. Stud. 25:616-636.

Wilde, P. J. 2000. Interfaces: Their role in foam and emulsion behavior. Curr. Opin. Colloid Interface Sci. 5:176-181.

Wright, B. J., S. E. Zevchak, J. M. Wright, and M. A. Drake. 2009 The impact of agglomeration and storage on flavor and flavor stability of whey protein concentrate 80 and whey protein isolate. J. Food Sci. 74:S17-S29.

Wright, J. W., M. E. Whetstine, R. E. Miracle, and M. A. Drake. 2006 Characterization of cabbage off-flavor in whey protein isolate. J. Food Sci. 71:C86-C90.

Zulewska, J., M. Newbold, and D. M. Barbano. 2009. Efficiency of serum protein removal from skim milk with ceramic and polymeric membranes at $50^{\circ}$ C. J. Dairy Sci. 92:1361-1377. 